\title{
Panchkarma and its Modality towards the Management of Pain and Related
}

\section{Disorders}

\author{
Available online at www.hjhs.co.in
}

REVIEW ARTICLE

\author{
Neeraj Kanungo ${ }^{a}$, Ajit Kumar Ojha ${ }^{\text {b }}$, Vijayata Kanungo ${ }^{c}$
}

${ }^{\mathrm{a}}$ M.D. Kayachikitsa, Assistant Professor, Kayachikitsa, Government Ashtanga Ayurved College and Hospital, Indore (M.P.) India.

${ }^{\mathrm{b}}$ M.D. Kayachikitsa, Assistant Professor, Panchakarma, Government Ashtanga Ayurved College and Hospital, Indore (M.P.) India.

${ }^{c}$ M.D. (Panchakarma), Panchakarma Specialist, Indore (M.P.) India.

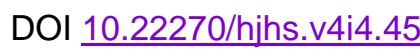

\section{ABSTRACT}

Ayurveda the science of healing and health restoration encompasses various therapeutic modalities for the treatment of disease and health management, Panchkarma is one such approach of Ayurveda that provides health benefits in many ailments including joint pain. The incidences of pain related diseases increases now a days due to the disturbed pattern of daily regimen and sedentary life style thus it is prerequisite to explore an approach that offers beneficial effects in these conditions without severe side effects and Panchkarma can provide therapeutic response in conditions like; osteoarthritis, sports injuries, rheumatoid arthritis, spondylosis, sciatica, myalgia, muscle cramps, sprain and low back ache, etc. Present article summarizes health benefits of Panchkarma in conditions related to pain or joint pain.

Keywords: Ayurveda, Pain, Joint Pain, Panchkarma, Basti.

\section{Introduction}

Pain or joint pain is mainly associated with aging or diseased conditions. As per Ayurveda the accumulation of toxin can trigger pathogenesis of pain. The accumulation of toxins causes imbalance of Doshas and diminish state of Dhatu thus induces cascade of inflammation that ultimately leads pain/ joints pain. The conditions associated with loss of flexibility, tenderness, weakness, swelling and restriction in movement. Therefore uses of purification measure recommended to alleviate root cause of pain, these Shodhna techniques not only removes toxins from body but also imparts soothing effects thus relieve pain sensation. Panchkarma is one of that modality which offers beneficial effects in conditions related to pain. (1-5)

Panchkarma is Ayurveda technique that detoxifies mind and body, it improves immune system, balances Doshas, improves metabolism, nourishes body and improves internal strength. Vamana Karma Virechana Karma Basti karma Nasya Karma and Rakta Mokshana are major actions of Panchkarma. Generally Panchkarma performed in three stages Purva Karma, Pradhan Karma and Paschat Karma. The Purva Karma mainly aims to prepare patient for main procedure using techniques like; oleation and Swedana. The Pradhan Karma involves conduction of main procedure, specific procedure out of five utilizes for particular therapeutic responses. Finally Paschat Karma performed for relaxation purpose. The Paschat Karma involves advises related to diet and daily living pattern in order to acquire maximum health benefits of therapy. (4-7)

Panchkarma not only relive pain but also help in stiffness, swelling and tenderness. The Panchkarma promote strength, enhance circulation, boost mobility and imparts calming effects thus help in the management of joint pain. The Ayurveda modality Panchkarma utilizes different technique for 
relieving pain such as; Swedana, Basti, Shirodhara and Nasya Karma, etc. Panchkarma cleans toxins and clear blockages thus improve overall digestive and circulatory system of body that enhances nutritional supply and regularization of metabolic activities. Panchkarma maintain flow of Vatta Dosha thus reduces pain related to vitiated Vata i.e; arthritis. Figure 1 depicted symptom related to pain disorders that can be alleviated by Panchkarma. (6-10)

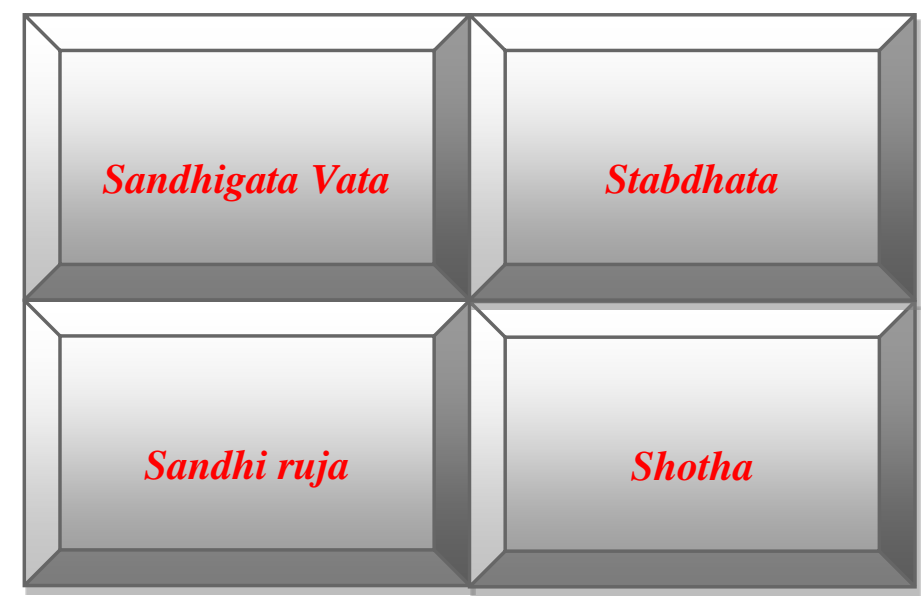

Figure 1. Common symptoms associated with pain and inflammation

\section{General health benefits of Panchakarma}

$>$ Eliminate toxins from body

$>$ Strengthen immune system

$>$ Maintain constitutional balances of body

$>$ Imparts mental and physical calmness thus relieve stress

$>$ Boosts strength, vitality and delay aging process

$>$ Improves circulation by opening minute channels

$>$ Improves metabolic and digestive activities

$>$ Regularizes hormonal and nutritional supply

\section{Basti in pain}

Basti improves Vatta Dosha circulation in body thereby reduces joint pain associated with Vata aggravation.

\section{Abhyanga in pain}

Abhyanga pacifies Vata, nourishes body, reduces stress and provide calming effects thus helps to relieve. It offers beneficial effects in case of conditions like; spondylitis, arthritis and muscle cramps etc.

\section{Swedana in pain}

It softens the muscles, relaxes tissues and dilates vessels for circulation thus helps to relieve pain. Swedana opens pores, strengthens spine, reduces swelling \& stiffness and relieve general symptoms of inflammation or pain.

\section{Kati Vasti in pain:}

The therapy involves use of warm oils over the lower back or spine parts of body for some period of time that helps to relieve lower back pain. The therapy alleviates numbness associated with nerve compression; Kati Vasti strengthens muscles thus help to main integrity of spine and bony tissues. It helps in spinal disorders, stiffness, spinal disc problems, spondylosis, sciatica and backache. The therapy increases circulation, strengthens the joints, nourishes nerves and imparts soothing effects thus helps in the management of back pain and spinal problem. After the conduction of therapy patient is suggested to avoid bending or lifting.

\section{Janu Basti in pain}

Janu means "knee", thus Basti around Janu is called Janu basti that offers lubrication to the joints reduces stiffening and rejuvenated synovial fluid. It relieves knee joints pain, prevents degenerative pathogenesis and strengthen knee. It helps in the treatment of osteoarthritis and patellar tendinitis. Janu basti 
strengthen knee muscles and knee joints thus rejuvenate functioning of knee. It pacify aggravated Vatta thus offers beneficial effects in chronic pain, knee sprain and bursitis.

\section{Greeva Basti in pain}

Greeva Basti means use of Basti Karma around neck region to relief pain from neck area. The therapy utilizes bathing of neck area with medicated oil that offers beneficial effects in cervical spondylosis, muscular strain, stiff neck and movement restriction. Therapy reduces swelling, tenderness and loosen the muscles thus enhances flexibility that restore free movement. The circulation enhanced around affected area leading to empowerment of natural healing process to relief symptoms of injury.

\section{Shirodhara in pain}

Shirodhara means streaming of oil through the head, the warm herbal medicated oil poured as stream over the forehead where nerves supply are highly concentrated. The oil pressure creates vibration over forehead and penetrates into the nervous system. The oil stimulates hypothalamus and pituitary gland thus induces sleep, calmness and relaxes mind along with nerves tissue. The oils causes vasodilatation, open up channels and improve brain blood circulation thus reduces stress hormone level and relieve pain sensation.

\section{Virechana in pain}

Virechana means use of purgatives that primarily helps in Vatarakta and other Vata Dosha, it cleans body from toxins. The Tikshna, Ushna and Sukshma Guna of Virechana drugs by virtue of their potency circulate throughout the body. It liquefies morbid Doshas and expelled them out through anal route. It control Srotorodha, normalizes Pratiloma Gati of Vata and enhances circulatory process thus helps in diseases related to aggravated Vata like; arthritis.

\section{Navan Nasya in pain}

Navan Nasya is Sneha Nasya in which Sneha or medicated Sneha is used generally. It is two types depending upon the quantity of Sneha dravya; Marsha \& Pratimarsha Nasya. The procedure involves administration of drugs into nostrils through dropper when patient sleep in supine position, head should be bent backward with 45 degree angle. Gandush (gargling) can be used to remove medicine that reaches throat. It offers relief in pain associated with Vata Kapha dominancy. This Nasya is gateway of Shira therefore relief pain sensation and imparts mental relaxation. The drug reaches Shira and eliminates vitiated Doshas and pacifies diseases related to upper body part. This therapy relief pain and other symptoms related to neuralgia, paralysis, headache, migraine and sinusitis.

\section{The modalities of Panchkarma offer following benefits in pain or related} diseases:

$>$ Panchkarma promotes health of bony tissue.

$>$ It helps in healing of fracture.

$>$ Improve range of movements.

$>$ Suppress pain intensity.

$>$ Help to treat muscular dystrophy.

$>$ Offer benefits in hyperurecemia.

$>$ Relief swelling, burning sensation and stiffness of joints.

$>$ Detoxify body and control serum uric acid level thus chances of disease like gout reduced.

\section{Conclusion}

The Panchkarma modalities such as; Kshara basti, Vaitaran basti and Saindhavadi taila basti offers great advantages in musculoskeletal disorders related to pain. The Panchkarma provides Vata Shaman effects thus relieve symptoms of osteoarthritis, sciatica and spondolytic disease, etc. The pacification of Vata by Panchkarma also helps in the management of Vatarakta. The detoxifying effects of Panchkarma expel out aggravated Ama thus helps in reduction of pain, swelling, stiffness and tenderness, etc. Shodhana process balances vitiated Dosha, facilitate evacuation of toxins, improves circulation, relaxes muscles, boosts nutritional supply and imparts calming effects therefore help to reduces pain, swelling, tenderness, stiffness and joint inflammation.

\section{Acknowledgements}


I would like to express my gratitude to Himalayan Journal of Health Sciences who gave me the opportunity to publish the article.

Financial Disclosure statement: The author received no specific funding for this work.

\section{Conflict of Interest}

The author declares that there is no conflict of interest regarding the publication of this article.

\section{References}

1. Trikamji Y. Editor. Sushruta samhita with Nibandhsangrah First edition, Varanasi: Chaukhambha Sankrit Santahan; 2012.p.261-70.

2. Shastri S. Ashtanga Hridaya sarvangsundara. First edition. Varanasi: Chaukhambha Surbharti Prakashan; 2017 .p.223.

3. Patil V. Essentials of practical Panchakarma therapy. Edition 1st. New Delhi: Chaukhambha Publications; 2015.p.274

4. Sayyed A. Kulkarni S. Kulkarni E. Kulkarni R. Clinical evaluation of Panchatikta Ksheer Basti in Sandhigata vata w.s.r.to osteoarthritis of knee joint.
Indian Journal of Pharmaceutical Science \& Research. 2017;:7(1):23-9

5. Shastri BS. editor. 6th ed. Vol. I. Varanasi: Chaukhamba Sanskrit Sansthan; 1997.p.565. (Yogaratnakara of unknown author, Amavata Nidana).

6. Nidana Madhava. In: M. Ni. 13th edition. 21. Upadhaya Yadunandana., editor. Vol. 22. Varanasi: Chaukhambha Sanskrit Sansthan; 2002. p. 463

7. Tripathi B. Madhavnidanam Madhukosha tika by vijayrakshita and Srikanthdatta. Vol. I. Varanasi: Chaukhambha Surbharati Prakashan; 2012 .p.551.

8. Gupta A, Thakar A, Shah N. Effect of Majja Basti (therapeutic enema) and Asthi Shrinkhala (Cissus quadrangularis) in the management of Osteoporosis (Asthi-Majjakshaya). AYU (An International Quarterly Journal of Research in Ayurveda). 2012;33(1):110

9. Katariya A, Jogalekar N. Basti chikitsa in Vatarakta w.s.r.to Hyperurecemia- a pilot study. Unique journal of ayurveda and herbal medicines. 2015;03(04):58-60

10. Susruta Samhita Sutra (26/10), Ayurved Tattva Sandipika Hindi Commentary by Ambika Datta Shastri. 12th edi. Varanasi: Chaukhambha Sansakrit Sansthan; 2001. 